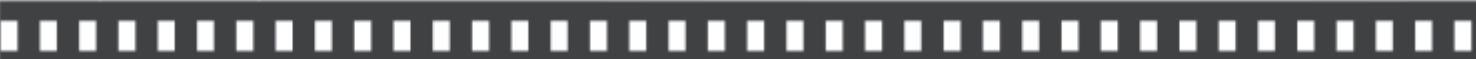

\author{
A função informativa da legenda fotográfica: \\ 0 massacre de Realengo
}

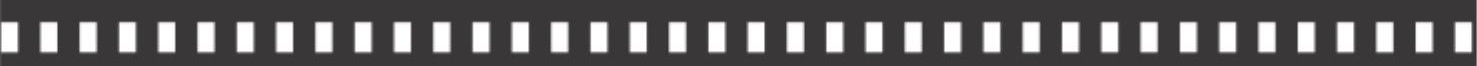

Luiza Lusvarghi

Mônica Zarattini 


\title{
A função informativa da legenda fotográfica: 0 massacre de Realengo
}

The informative function of photographic captions: the Realengo massacre

\author{
LuizaLusvarghi* \\ MônicaZarattini**
}

\begin{abstract}
Resumo: $O$ artigo visa investigar a função informativa da legenda fotográfica e como as linguagens visual e escrita se relacionam nos jornais diários brasileiros. As edições de 36 capas de jornais de todas as regiões do país do dia 8 de abril de 2011 sobre o massacre do Realengo foram analisadas. Com o suporte teórico de Roland Barthes, Martine Joly, Milton Guran, Jorge Santos e Ivan Lima foram selecionadas as legendas de duas imagens que se repetiram em mais da metade do corpus. Na maioria dos casos, as legendas fotográficas não cumpriram a função informativa, mas sim a descritiva e a opinativa.
\end{abstract}

Palavras-chave: Fotografia. Fotojornalismo. Legenda. Mensagem jornalística.

\begin{abstract}
This article aims to investigate the informative purpose of photographic captions and the relationship of visual and written languages in Brazilian daily newspapers. The front pages of 36 newspapers from every region of Brazil on April 8 2011, regarding the Realengo massacre were analyzed. With theoretical support from Roland Barthes, Martine Joly, Milton Guran, Jorge Santos and Ivan Lima the captions from two images that were repeated in nearly half the material analyzed, were selected. In the majority of cases the photographic captions do not fulfill their informative purpose, instead providing descriptions and opinions.
\end{abstract}

Keywords: Photography. Photojournalism. Caption. Editorial message.

* Professora de teoria do jornalismo na Universidade Nove de Julho (Uninove), de São Paulo. Mestre e doutora em Ciências da Comunicação pela Escola de Comunicação e Artes da Universidade de São Paulo (ECA/USP). Pós-doutora pela Universidade Federal de Pernambuco (UFPE), com pesquisa sobre os grupos de mídia regional. E-mail: lumecom@uol.com.br

** Editora de fotografia do Jornal da Tarde e de O Estado de S. Paulo, onde trabalha há 23 anos. Mestranda em Ciências da Comunicação pela Escola de Comunicação e Artes da Universidade de São Paulo (ECA/USP), sob orientação do Prof. Dr. Eugênio Bucci. E-mail: zara@usp.br 


\section{Introdução}

Ao ler as legendas fotográficas de alguns jornais diários brasileiros percebe-se que, em uma grande parte delas, o conteúdo da mensagem escrita nem sempre está de acordo com o que se vê na fotografia. Essa contradição leva à imediata indagação: a legenda fotográfica cumpre ou não sua função informativa na transmissão da mensagem jornalística?

A mensagem jornalística é composta por várias estruturas concorrentes que se somam como a manchete, o artigo, os títulos, os subtítulos, as legendas, as fotografias, os gráficos, as charges, as artes e as ilustrações. A relação entre a fotografia e a sua legenda é de complementaridade ou é de dependência? Como esse conjunto (texto e fotografia), intermediada pela legenda, proporciona a informação necessária ao leitor?

No jornalismo impresso contemporâneo brasileiro, salvo raras exceções, as fotografias estampadas nas páginas vêm acompanhadas de legendas que podem estar abaixo, ao lado ou, algumas vezes, até dentro da imagem. Dificilmente fotografias jornalísticas vêm desacompanhadas de legendas. Neste trabalho, o objeto de estudo será a legenda fotográfica e a investigação da seguinte questão: a legenda fotográfica cumpre sua função informativa na mensagem jornalística? A partir deste problema, surgem outras interrogações: a fotografia jornalística depende da legenda para ser compreendida pelo leitor? A hipótese apresentada é que a legenda fotográfica, nos dias atuais, raras vezes cumpre sua função informativa e, na maioria dos casos, como um elo entre a fotografia e o texto, apenas reforça a mensagem escolhida pelo veículo de comunicação.

O universo da pesquisa foi composto por 36 capas de jornais impressos brasileiros do dia 8 de abril de 2011, data em que a maioria editou o massacre do Realengo como notícia principal ou como notícia única. No episódio, ocorrido no bairro do Realengo, no Rio de Janeiro, um atirador entrou em uma escola matando 12 crianças e ferindo outras 
12. O caso repercutiu nacional e internacionalmente, o que facilitou estudos comparativos. No corpus de capas de todas as regiões do país, observouse que três imagens se repetiram em mais da metade dos jornais.

As fotografias são do mesmo autor, o repórter fotográfico Jadson Marques, com mais de dez anos de experiência em coberturas policiais. Ele fotografava para $O$ Dia, jornal carioca para o qual prestava serviços como free-lancer. Contatado por telefone, dia 9 de maio de 2011, ele colaborou com a pesquisa e nos enviou as imagens por e-mail, tal como as havia enviado dia 7 de abril de 2011 para as agências nacionais e internacionais que as espalharam para o Brasil e o mundo, com a legenda original, por ele redigida. Duas das imagens são do corpo do atirador assassino, Wellington Menezes de Oliveira, caído na escada da escola. A outra é a de uma mulher chorando, rodeada por uma adolescente e outras pessoas ao fundo, atrás de dois braços de policiais militares que, pela farda, parecem ser bombeiros. Essas imagens apareceram nas capas de 19 dos 36 jornais pesquisados (Gráfico 1). Todas as legendas que as acompanhavam foram relacionadas - e reproduzidas - para este estudo comparativo.

Para investigar a função informativa da legenda fotográfica e as relações entre mensagens visuais e escritas, obras dos autores Roland Barthes, Martine Joly, Milton Guran, Jorge Santos e Ivan Lima foram utilizadas como suportes teóricos, assim como as políticas editoriais contidas nos manuais de redação dos três maiores jornais impressos de circulação nacional: $O$ Estado de S. Paulo, Folha de S. Paulo e $O$ Globo. O objetivo principal é o de contribuir para ampliar a discussão e promover uma revisão bibliográfica sobre o assunto. 
Gráfico 1 - Número de jornais, por região, que publicaram na capa as duas imagens estudadas nesse trabalho ${ }^{1}$

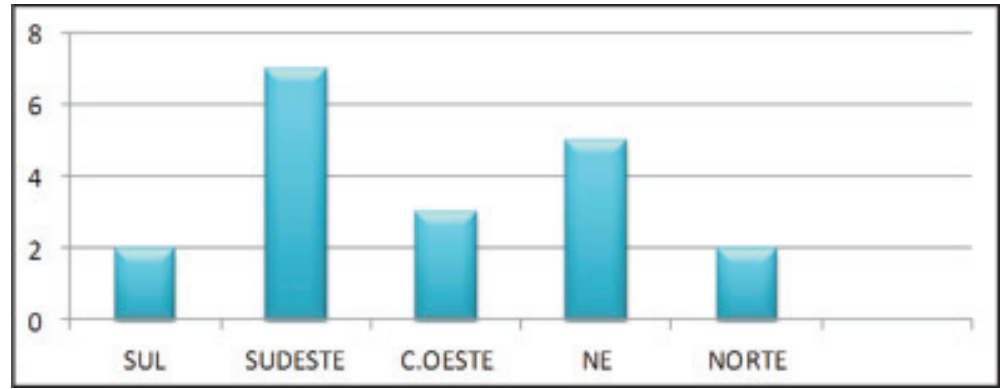

Fonte: Gráfico elaborado por Mônica Zarattini

\section{Conceitos de legenda fotográfica}

Em O óbvio e o obtuso, Barthes (1990) assinala que a mensagem jornalística está apoiada em duas estruturas, a linguística e a visual. Editar é escolher entre o espaço que será dado ao texto e o que será dado à fotografia, de acordo com a importância e relevância da mensagem (notícia) que se quer publicar. As duas estruturas, a linguística e a visual, são concorrentes, porém heterogêneas: "No texto a substância da mensagem é constituída por palavras; na fotografia, por linhas, superfícies, matizes." (BARTHES, 1990, p.12). Portanto, elas não se confundem, mas "brigam" o tempo todo para ocupar o espaço de maior destaque disponível na diagramação adotada pelo veículo de comunicação. Barthes (1990, p.11) acredita que, neste conjunto de mensagens, a fotografia é o centro, circundada pelo texto, título, legenda e diagramação.

Prosseguindo em seu raciocínio, Barthes (1990) identifica o conteúdo da mensagem fotográfica (denotada) diferenciando-o do conteúdo da mensagem do texto (conotada). A mensagem escrita é cheia de códigos, palavras que se unem para formar um significado; na mensagem visual expressa no jornal, como na fotografia, não há códigos, pois ela pretende

1 Para visualizar as capas dos 19 jornais relacionados no Gráfico 1, Acessar : http://migre.me/ 5 vo6 W 
ser o analogon da realidade, e é aí que reside seu caráter mítico. O senso comum do público define a fotografia como cópia perfeita pela plenitude de sua analogia na transmissão do real.

A "perfeição" e a "objetividade" da natureza da fotografia, hoje digital, e sua capacidade de selecionar e representar aspectos do real da maneira como se parecem, conferem à fotografia um elevado grau de credibilidade. (KOSSOY, 2002, p.19). Ao ver uma fotografia, o sentimento de "denotação", ou de plenitude analógica com o real, é tão forte que seria impossível descrevê-la ao pé da letra. Neste sentido, segundo Barthes (1990, p.14), qualquer descrição seria acrescentar a ela uma segunda mensagem. Esta segunda mensagem, a conotada, às vezes clara, às vezes implícita, viria de duas vertentes: a primeira da maneira pela qual o fotógrafo visualiza os fatos e acontecimentos para construir sua fotografia; a segunda, numa fase posterior, quando esta mesma fotografia vier acompanhada por uma legenda na página do jornal, que poderá - ou não - conotá-la. Vejamos como se dá esta produção.

Ao receber uma determinada pauta de seu editor, o repórter fotográfico se dirige ao local do acontecimento. Durante o deslocamento, ele começa a elaborar um conjunto de ideias sobre o fato jornalístico que irá cobrir. Ao chegar ao local, decidirá o recorte espacial do enquadramento, a mobilidade - ou não - do tema (movimento ou congelamento) e a profundidade de campo - ou não - do que pretende fotografar. Todo seu repertório, cultural, ideológico, sensitivo, estético, técnico será determinante no seu testemunho e no processo de criação da imagem e representação do real. (KOSSOY, 2002, p.52).

Num instante, o fotógrafo coloca no mesmo eixo a mente, o olho e o coração para comunicar, num átimo de segundo, o corte de uma cena que resultará numa imagem única. (CARTIER-BRESSON, 1965, p.3). Ele lançará mão de todos os elementos da linguagem fotográfica e dos recursos técnicos que dispõe (lentes, foco, abertura do diafragma, tempo de exposição e outros) para comunicar ao leitor uma determinada parte da realidade que está presenciando. Entre ele e o real existe uma câmera que congelará o determinado espaço por ele visualizado e pensado. 
Independente dos avanços tecnológicos há um consenso de que entre o fato ocorrido e a fotografia estampada na página de um jornal, existiu um sujeito, o repórter fotográfico, que esteve no local e testemunhou o acontecimento. É isso que confere credibilidade e sensação de veracidade à fotografia. No entanto, também é consenso que a fotografia estampada em um jornal para informar sobre uma notícia passou pelo filtro cultural e ideológico do repórter fotográfico. Assim, ao mesmo tempo em que estampa mensagem denotada, a fotografia também traz a mensagem conotada pelo fotógrafo.

Num segundo momento, da pós-produção e edição, a legenda será anexada pelo editor da página. Acredita-se que no processo diário da confecção de um jornal, a legenda não seja escrita pelo autor da imagem, ou seja, o repórter fotográfico. É o que ocorre no Grupo Estado, onde existem dois procedimentos distintos: no jornal O Estado de S. Paulo, o diagramador, ao colocar a fotografia indicada pelo editor de fotografia na página, além de atribuir o crédito ao fotógrafo, acima ou ao lado da fotografia, "cola" no espaço destinado à legenda, geralmente abaixo da fotografia, o que está escrito na legenda original, feita pelo repórter fotográfico. Com isso, o redator ou o editor que fechará a página tem acesso à sugestão original de legenda. Já no Jornal da Tarde, o procedimento é outro: o diagramador dispõe a fotografia indicada pelo editor de fotografia no espaço esperado, mas o crédito e a redação da legenda ficam por conta do editor ou "fechador" da respectiva editoria (cidades, economia, esportes etc.), que pode ou não ler a legenda original, feita pelo repórter fotográfico. Os procedimentos de redação das legendas podem ser diferentes de jornal para jornal. Dificilmente a legenda utilizada no processo de finalização da página é a redigida pelo repórter fotográfico.

Barthes (1990) aponta três observações sobre como a legenda pode conotar a fotografia que, por si só, seria uma estrutura de informação constituída por mensagem "denotada" que esgotaria totalmente seu ser. Primeiro, ele considera o texto "uma mensagem parasita, destinada a conotar a imagem, isto é, 'insuflar-lhe' um ou vários significados segundos". (BARTHES, 1990, p.20). Esses significados segundos do texto ou da 
legenda racionalizam a imagem determinando uma cultura, uma moral, um imaginário que se estende além da mensagem da fotografia jornalística apresentada.

A segunda observação diz respeito à disposição da fotografia na página do jornal. Quanto mais próxima a palavra estiver da imagem, menos ela terá poder de conotá-la. A mensagem iconográfica é mais forte e "devora" a mensagem verbal: "A legenda tem, provavelmente, um efeito menos evidente do que a manchete ou o artigo." (BARTHES, 1990, p.20). Apesar de serem estruturas diferentes, legenda e fotografia se mesclam e a legenda, por sua disposição, acaba por participar da denotação da fotografia.

Na terceira observação, Barthes (1990) destaca que a palavra não consegue "duplicar" a fotografia, mas a legenda pode inventar e atribuir-lhe novos significados, e essa tem se tornado uma prática muito comum nos dias atuais.

\begin{abstract}
Trata-se aparentemente de uma explicitação, isto é, dentro de certos limites, de uma ênfase; na maioria das vezes o texto limitase a ampliar um conjunto de conotações já incluídas na fotografia; mas, por vezes, também o texto produz (inventa) um significado inteiramente novo, que é de certo modo, projetado retroativamente na imagem, a ponto de nela parecer denotado [...]. Por vezes, a palavra pode chegar a contradizer a imagem, produzindo uma conotação compensadora. (BARTHES, 1990, p.21).
\end{abstract}

Os atuais manuais de redação da Folha e do Estado indicam que a legenda deve descrever a fotografia e acrescentar "opiniões", colidindo com as ideias de Barthes.

Manual da Folha de S. Paulo: Recurso essencial de edição. A legenda não é colocada sob a foto apenas para descrevê-la, embora não possa deixar de cumprir essa função. Por ser um dos primeiros elementos da página que atrai o leitor, merece tanto cuidado quanto os títulos. Deve ser atraente e conquistar a atenção. A boa legenda também esclarece qualquer dúvida que a foto possa suscitar. Deve salientar todo aspecto relevante e dar informação 
adicional sobre o contexto em que ela foi tirada. Não deve simplesmente descrever aquilo que qualquer leitor pode ver por si só. A legenda fotográfica deve atender à curiosidade do leitor, que deseja saber o que ou quem aparece na foto, o que está fazendo, onde está. Sempre que for cabível, deve usar verbo no presente (o presente do momento em que a foto foi tirada). (SILVA, 2010,p.78).

Manual de O Estado de S. Paulo: As legendas, no Estado, devem, sempre que possível, cumprir duas funções, simultaneamente: descrever a foto, com verbo de preferência no presente, e dar uma informação ou opinião sobre o acontecimento. (MARTINS, 1997, p.159).

O manual de $O$ Globo, por sua vez, não orienta a descrição da imagem, só em "casos de cenas muito complexas". (GARCIA, 1999, p.48).

Manual de $\boldsymbol{O}$ Globo: Complementa a foto acrescentando-lhe informações que permitem ao leitor entender ou avaliar o que está vendo. Assim como a boa notícia, a boa legenda responde a todas as perguntas razoáveis do leitor. Ela identifica os personagens (todas as pessoas importantes em si, ou importantes na notícia, tem de ser identificadas), o lugar, o momento. Em alguns casos chama a atenção pelo detalhe significativo que possa escapar à atenção do leitor.

A não ser em casos de cenas muito complexas, é redundante descrever na legenda o que se vê na foto, aquilo que a imagem deixa óbvio. Não se usa o espaço para isso, mas para fornecer informações que a foto não pode dar - como quando a foto mostra um jogador no momento em que chuta a bola, só a legenda pode dizer se houve gol. (GARCIA, 1999, p.48).

Em Introdução à analise da imagem, Martine Joly (2004, p.116) defende o contexto de complementaridade nas relações das imagens com as palavras e critica o pensamento corrente de que a "proliferação da imagem" possa excluir a civilização do texto. Para a autora, as linguagens verbal e escrita quase sempre acompanham as imagens. A fotografia, por ser uma imagem fixa, não tem capacidade de contar uma história com as 
relações temporais e causais, como o cinema, onde há uma sequência de imagens, e, portanto, são as palavras que vão complementar a imagem (e a história). Há interação entre as palavras e as imagens que se complementam e se esclarecem umas às outras. O leitor julga uma fotografia falsa ou verdadeira não devido ao que ela representa, mas sim ao que é dito ou escrito sobre ela.

Portanto, as imagens mudam os textos, mas os textos por sua vez, mudam as imagens. $\mathrm{O}$ que lemos ou ouvimos a respeito das imagens, a maneira como a literatura, a imprensa, a sinalização apropriam-se delas, trituram-nas e apresentam-nas determina necessariamente a abordagem que fazemos delas. (JOLY, 2004, p.131).

Em Linguagem fotográfica e informação, Milton Guran (2002, p.51) enfatiza que a relação da fotografia com o texto é explicitada através da legenda fotográfica: "A legenda deve suprir o leitor de informações não contidas ou não evidentes na imagem.” Destaca que a função da legenda deve ser a de um "gatilho mental", que ative no leitor informações a respeito da imagem publicada, fazendo com que ele se interesse mais pelo assunto e, desta forma, explore melhor a fotografia: "No entanto, uma legenda do tipo descritivo redundante - 'na foto, Fulano de Tal, com um livro na mão, oferece-o a Sicrano' - induz ao desinteresse, banalizando a foto." (GURAN, 2002, p.51).

Em A fotografia é a sua linguagem, Ivan Lima (1988, p.31) considera que a fotografia é produto de uma relação espaço/tempo, na qual o fotógrafo decide qual instante (tempo) e qual enquadramento (espaço) deve recortar ao construir sua imagem. Segundo o autor, a legenda "é parte integrante de uma fotografia" e cumpre a função de mediar a realidade vivida pelo repórter fotográfico e a imagem vista pelo leitor.

Outro importante aspecto levantado por Lima (1988) é acerca da escolha da imagem pelo editor. Segundo o autor, nem sempre a imagem escolhida pelo editor é a que melhor representa a mensagem que o jornal quer emitir. Em casos como esse, ainda segundo Lima (1988, p.32), as 
legendas não endossam a imagem e, não raro, mudam seu significado para se adequar ao discurso proposto.

Em seu artigo Operadores de tempo em enunciados de legendas jornalísticas, Jorge Viana Santos (2005, p.1091, grifo do autor) afirma que a legenda fotográfica é um enunciado que tem estrutura paralela à notícia pois ela especifica "dados ligados ao acontecimento, referindo elementos: o que, quem, onde e quando". O autor considera a legenda um signo entre o verbal (notícia) e o visual (fotografia), que teria dois segmentos: o primeiro busca referentes na imagem e o segundo em aspectos da notícia não mostrados na imagem. Ele salienta que, em geral, as legendas empregam operadores de tempo (advérbios temporais e preposições) e "o agora do tempo lingüístico ancora-se também no agora do tempo da imagem" (SANTOS, 2005, p.1091, grifo do autor), reforçando o sentido de complementaridade de Joly (2004), acrescentando que a fotografia não se classifica jornalística se não possuir uma legenda: "O papel desta última não é, como ingenuamente se diz, descrever aquela: é, muito mais, exercer o papel de extrapolá-la, fazê-la dizer o que não se vê, a partir do que se vê." (SANTOS, 2005, p.1091).

Em Realidades e ficções na trama fotográfica, Boris Kossoy (2002) destaca o papel da editoração da fotografia na imprensa, seja ela impressa ou digital. O processo de construção da representação na edição das fotografias veiculadas pelos meios de comunicação vai além do processo de criação do repórter fotográfico. Para ser inserida na página de um jornal, a imagem passa pelo processo de pós-produção, ou seja, é submetida a uma série de "adaptações".

Neste sentido, são muitas as possibilidades de manipulação elaboradas pelos meios de comunicação impressa. Desde sempre as imagens foram vulneráveis às alterações de seus significados em função do título que recebem, dos textos que 'ilustram', das legendas que as acompanham, da forma como são paginadas, dos contrapontos que estabelecem quando diagramadas com outras fotos etc. Tudo isso além de outras manipulações como a reutilização de uma mesma fotografia para servir de prova numa situação diferente - e, por vezes, até antagônica - daquela para 
qual foi produzida originalmente através, simplesmente, como já foi dito, da mera invenção de uma nova legenda ou título. (KOSSOY, 2002, p.55, grifo do autor).

\section{As fotografias e suas legendas}

Com apoio teórico dos autores supracitados, apresentamos a análise das três imagens e a comparação de suas legendas, publicadas em 19 jornais brasileiros. A primeira e a segunda fotografia (Figuras 1 e 2), consideradas de modo conjunto no estudo, são do corpo do assassino caído em uma escada da escola onde ocorreu o massacre; a terceira é a de uma mulher, entre outras, que chora e se destaca atrás de braços de policiais. Estas imagens são bem características do que Barthes (1990, p.24) chama de "foto-choque", aquelas que são traumáticas, como incêndios, naufrágios, mortes violentas, catástrofes, ou seja, são aquelas que falam por si só.

As imagens foram analisadas, primeiro, fora do contexto da página do jornal, para depois serem comparadas às legendas fotográficas que lhe foram atribuídas em cada veículo de comunicação.

Figuras 1 e 2 - Imagens do corpo de Wellington Menezes de Oliveira na escada da escola do bairro Realengo
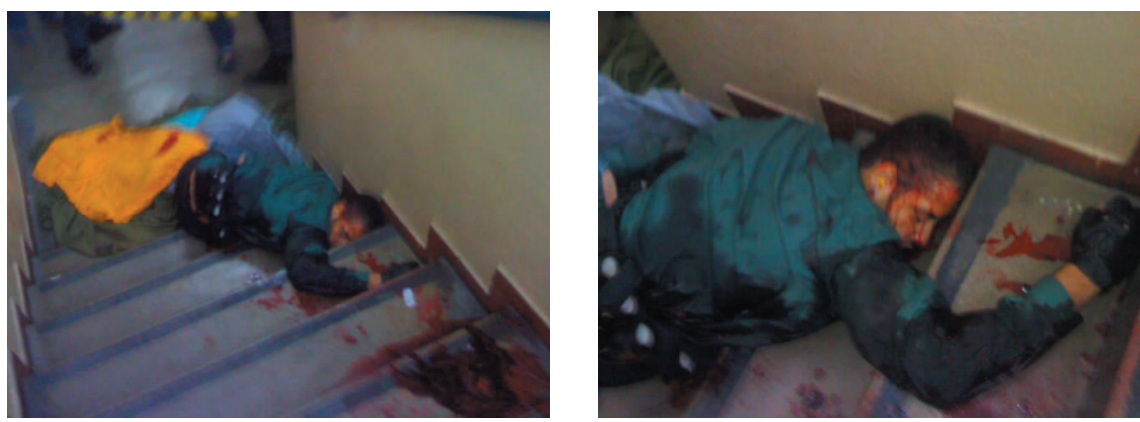

Fotografia: Jadson Marques / Reprodução

Fonte: Acervo pessoal de Jadson Marques ${ }^{2}$

${ }^{2}$ Como já explicitado, o repórter fotográfico Jadson Marques gentilmente enviou as imagens por e-mail. 
As figuras 1 e 2 mostram o corpo do assassino caído na escada. Parecem ter sido as únicas imagens dele morto à qual a imprensa teve acesso, pois foram repetidas inúmeras vezes nos telejornais. As fotografias foram feitas com um telefone celular, única "câmera fotográfica" que pôde chegar à cena do crime: uma das fotografias foi tomada com ângulo mais aberto e a outra com o ângulo um pouco mais fechado, mostrando o corpo do atirador da cintura para cima. Na imagem mais aberta, vê-se ao fundo uma fita amarela e preta. A fita funciona com um signo, revelando o isolamento do corpo. Atrás da fita de isolamento é possível perceber alguns pés. Plásticos e panos cobrem as pernas do assassino. Há um cinturão que parece carregar munições atado ao seu corpo. Ele veste uma luva na mão direita, o que pode sugerir a premeditação do crime. Muito sangue na escada indicia forte mensagem de violência. O rosto do assassino é parcialmente reconhecido. Na imagem mais fechada, pode-se ver um protetor acústico amarelo em seu ouvido direito.

As fotografias (Figuras 1 e 2) foram enviadas pelo repórter fotográfico Jadson Marques às agências nacionais e internacionais, dia 7 de abril de 2011, com a seguinte legenda (ipisis literis): "Rio.07/04/11. Alunos baleados na escola em Realengo. Na foto corpo do assassino. Foto Jadson Marques". No quadro 1, uma relação das legendas publicadas em alguns jornais:

Quadro 1 - Legendas de alguns jornais brasileiros para a fotografia do assassino da escola do Realengo

$\boldsymbol{O}$ Globo - "O assassino caído na escada após ser baleado e se suicidar"

Agora - "O corpo do atirador Wellington Menezes de Oliveira fica caído em uma escada da escola após ser atingido por um PM no abdômen e cometer suicídio com um tiro na boca"

Correio Braziliense - "O assassino, Wellington de Oliveira, deixou carta com teor religioso e orientação sobre o funeral" Amazônia - A fotografia aparece sem legenda, inserida em um conjunto de três fotografias 
Diário de Pernambuco-A fotografia aparece sem legenda, inserida em um conjunto de sete fotografias

Jornal de Brasília - A fotografia aparece sem legenda, inserida em um conjunto de seis fotografias

$\boldsymbol{O} \mathbf{D i}$ - A fotografia aparece sem legenda, inserida em um conjunto de nove fotografias

Figura 3

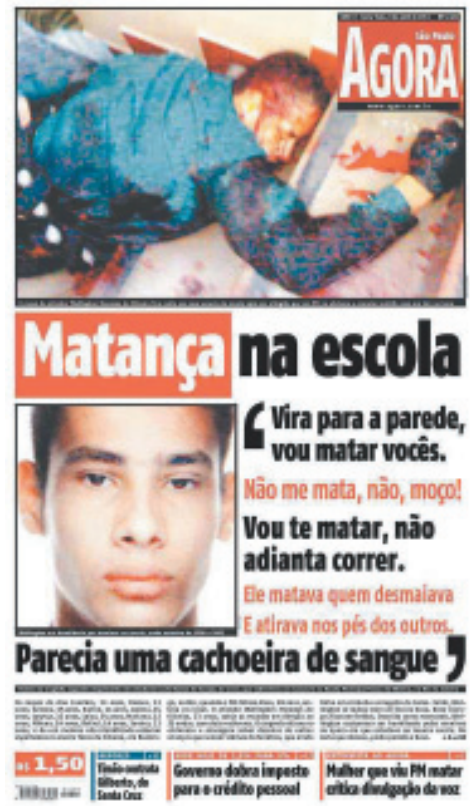

Fonte: Jornal Agora

Figura 4

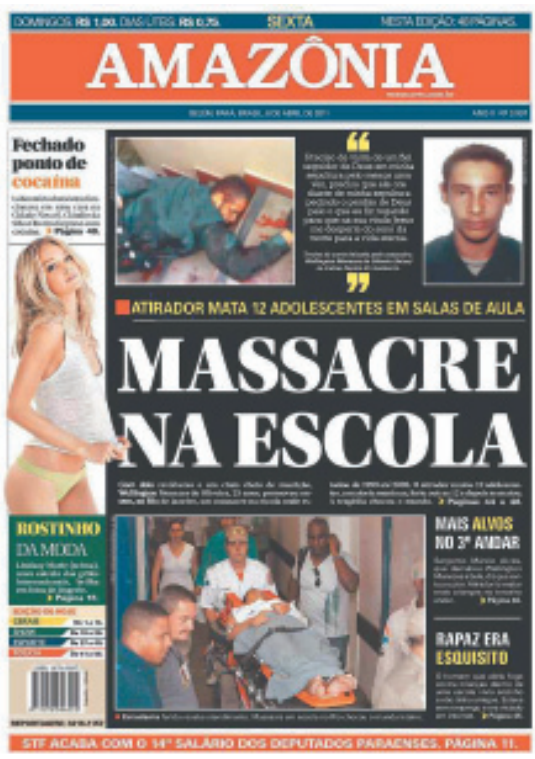

Fonte: Jornal Amazônia 
Figura 5

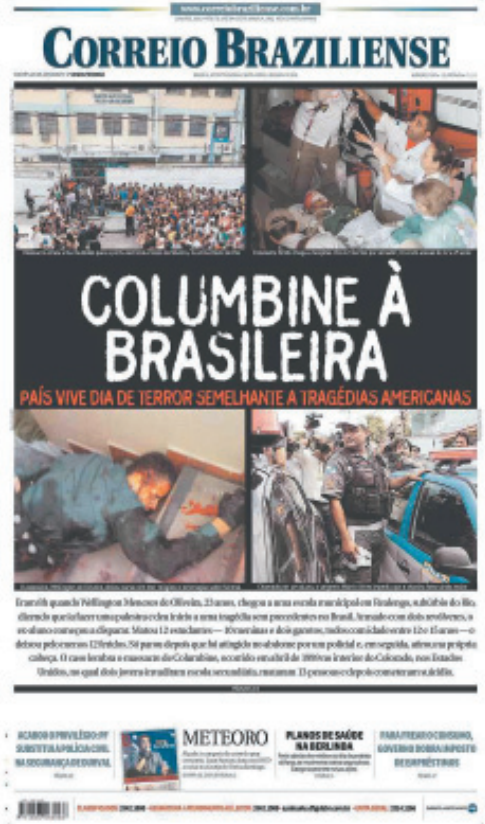

Fonte: Correio Braziliense

O jornal Agora (Figura 3) indica em sua legenda o local (escada da escola) e acrescenta informações da notícia (após ser atingido por um PM no abdômen e cometer suicídio com um tiro na boca). Essas informações, no entanto, em nada correspondem à leitura da fotografia; servem apenas para "comprovar" o discurso do jornal, cuja manchete foi "Matança na escola", e, de acordo com Barthes (1990, p.20), "insuflar-lhe um ou vários significados segundos". A fotografia do atirador ocupa quase metade da primeira página e se soma à reprodução de sua fotografia $3 \times 4$, que o mostra vivo, em tamanho significativo, reforçando ainda mais a mensagem do jornal.

A legenda, ao informar que o assassino levou um tiro no abdômen, disparado por um policial militar, e se suicidou com um tiro na boca - informações que não estão na imagem fotográfica -, atende o que prega o manual de redação da Folha de S. Paulo, empresa à qual o jornal 
Agora pertence, para a legenda fotográfica, ou seja, “dar informação adicional sobre o contexto em que ela foi tirada". (SILVA, 2010, p.78).

Em três jornais, a fotografia do atirador aparece sem legenda, funcionando como um signo, pois em situações de dor ou tragédias, Barthes (1990, p.13) coloca que a mensagem denotada pela fotografia é tão forte que se esgota por si só. O jornal Amazônia (Figura 4) usou um recurso similar ao Agora, ou seja, também utilizou duas fotografias: a do assassino morto e a reprodução de uma fotografia sua, estilo 3x4, lado a lado, mas não usou legendas para identificar ou dar mais informações sobre as imagens. As fotografias, somadas a um trecho entre aspas da carta de Wellington Menezes de Oliveira e o subtítulo "Atirador mata 12 adolescentes em sala de aula", reforçam a mensagem da manchete do jornal: "MASSACRENA ESCOLA".

No Diário de Pernambuco, a fotografia também foi publicada sem legenda, inserida em um conjunto de sete imagens, dispostas ao lado da reprodução integral do texto da carta deixada pelo assassino. Somadas, estas duas estruturas - a linguística e a visual - parecem ilustrar e reforçar o intuito da manchete estampada pelo jornal: "12 MORTOS, 190 MILHÕES DE FERIDOS”. O jornal O Dia também não utilizou legenda para a fotografia do corpo do assassino. Ela, inclusive, foi editada entre outras nove imagens do massacre, acompanhadas de pequenos textos que formam uma espécie de "mosaico". Esta estratégia de programação visual está ancorada pela manchete. Nela, o jornal reproduziu uma frase que, segundo testemunhas, teria sido dita pelo assassino: "AJOELHA QUE EU VOU TE MATAR". O conjunto da obra - fotografias, pequenos textos em forma de mosaico e manchete - indicia uma mensagem sensacionalista que, ao que parece, seria a proposta do jornal. No Jornal de Brasília, a fotografia do assassino também aparece sem legenda. Ela e outras cinco imagens se unem à manchete "ATAQUE BRUTAL" e a um texto único, de caráter explicativo, com dados sobre o massacre.

A legenda do Correio Braziliense (Figura 5) identifica o assassino e informa que ele deixou uma carta com teor religioso. Esta segunda informação em nada se relaciona com a mensagem da fotografia. Mais 
parece uma tentativa de conotação para a adequação do conjunto à mensagem da manchete "COLUMBINE À BRASILEIRA", que induz o leitor a fazer comparações com o caso norte-americano. A informação da legenda "deixou carta com teor religioso e orientação sobre o funeral", por estar muito próxima à imagem, como lembra Barthes (1990, p.20), é devorada pela mensagem iconográfica, que é fortemente denotativa. De acordo com o raciocínio do autor, a legenda fornece uma informação que nada tem a ver com a mensagem vista, mas tenta impor uma imaginação e uma moral.

Figura 6 - Mulheres assustadas e desesperadas choram atrás dos braços de bombeiros

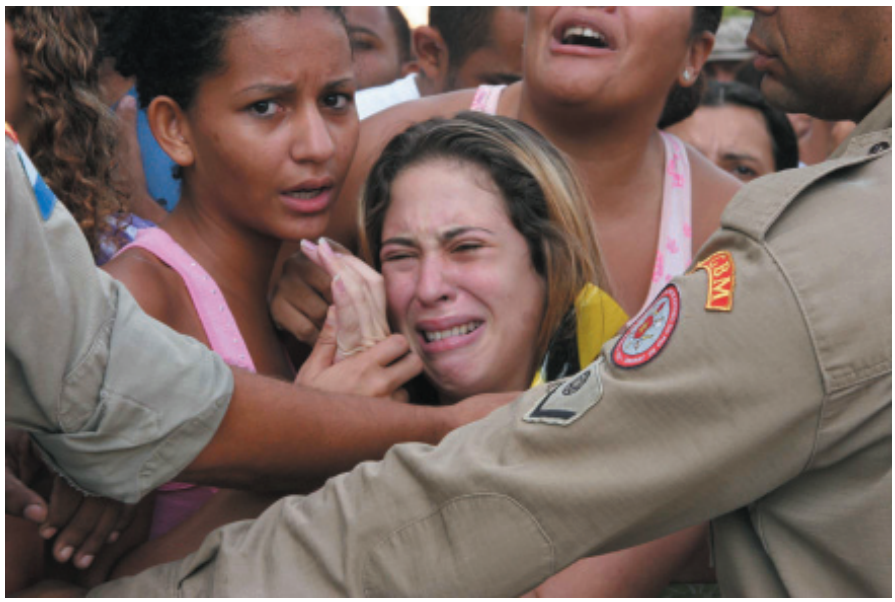

Fotografia: Jadson Marques / Reprodução

Fonte: Acervo pessoal de Jadson Marques

Na figura 6, a imagem central é de uma mulher que chora ao lado de uma adolescente que segura uma de suas mãos. Atrás dela surge o rosto de outra mulher, cortado do nariz para baixo, mas que mostra sua boca gritando, chorando ou lamentando. Elas estão atrás dos braços de dois policiais que parecem ser do corpo de bombeiros, pela cor da farda e pelo distintivo. Há um pequeno pedaço de fita plástica amarela e preta, signo que indica isolamento do lugar ou entre as pessoas. Atrás destas três mulheres se veem outras imagens fragmentadas de pessoas que 
parecem formar parte de uma multidão (pelo corte fechado da fotografia não há como ter a dimensão do tamanho da multidão). O repórter fotográfico Jadson Marques não sabia quem era a mulher. Com tantas situações para fotografar, ele não conseguiu anotar seu nome e contato, prática comum dos fotógrafos em coberturas jornalísticas conturbadas e trágicas. Na legenda original, que atribuiu à fotografia, escreveu apenas que eram "familiares".

O repórter fotográfico enviou a fotografia (Figura 6) para as agências nacionais e internacionais, dia 7 de abril de 2011, com a seguinte legenda (ipisis literis): "Rio. 07/04/11. Alunos baleados na escola em Realengo. Na foto, familiares dos alunos na porta da escola. Foto Jadson Marques". No quadro 2, uma relação das legendas publicadas em alguns jornais:

Quadro 2 - Legendas de alguns jornais brasileiros para a fotografia da suposta mãe de uma vítima do massacre

O Estado de S. Paulo - "Desespero. Parentes de vítimas reagem diante da Escola Municipal Tasso da Silveira, em Realengo, zona oeste do Rio"

A Notícia - "Desespero em frente à escola onde ocorreu o massacre"

A Tribuna - "Desespero. Familiares de vítimas ficam desorientados em busca de informações, enquanto corpos são retirados do local da matança. Jovens feridos são levados para hospital da região"

$\boldsymbol{O}$ Popular - "Familiares de alunos se desesperam atrás de notícias sobre o crime"

$\boldsymbol{A}$ Tarde - "Parentes de alunos se desesperam à espera de notícias das crianças"

Jornal da Cidade - "Mãe de vítima se desespera ao saber do assassinato em frente a escola no bairro do Realengo, no Rio"

Jornal de Jundiaí - "Mãe de aluno chora diante da escola onde aconteceu, ontem, a tragédia mais cruel de toda história do Brasil. Ataque que já marcou os EUA mais de uma vez, agora, choca o Brasil"'

Comércio da Franca - "Amparada por policiais, familiar de aluno se desespera em frente ao colégio" 
Diário de Natal - A fotografia aparece em um conjunto de quatro fotografias, com a seguinte legenda: "O assassino, Wellington Oliveira, 23 anos, deixou carta de suicídio com referência ao islamismo e diz ser portador do HIV"

Jornal de Brasília - A fotografia aparece sem legenda, inserida em um conjunto de seis fotografias.

$\boldsymbol{O} \boldsymbol{D i \boldsymbol { a }}$-A fotografia aparece sem legenda, inserida em um conjunto de nove imagens.

Diário do Pará - A fotografia aparece sem legenda, inserida em um conjunto de quatro fotografias.

$\boldsymbol{O}$ Norte - A fotografia aparece sem legenda, inserida em um conjunto de quatro imagens.

Diário Catarinense - A fotografia aparece como imagem única na capa, mas sem legenda.

Figura 7
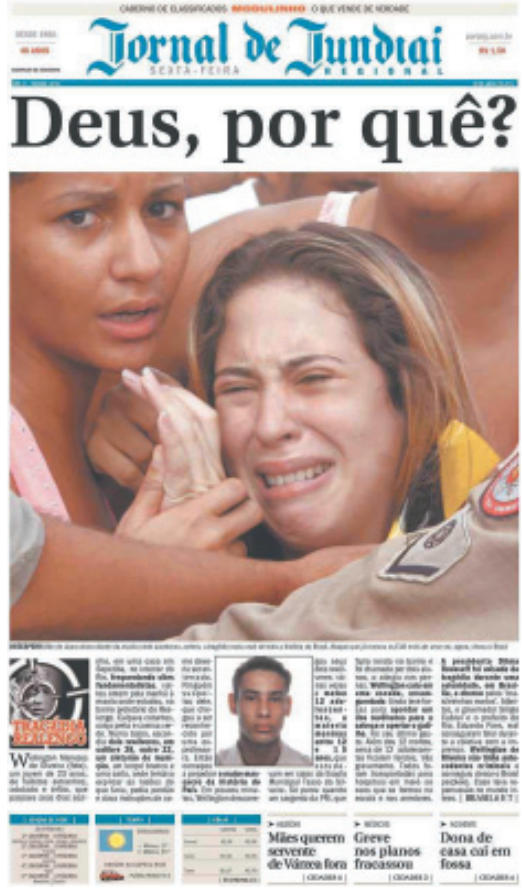

Fonte: Jornal de Jundiaí 
Figura 8

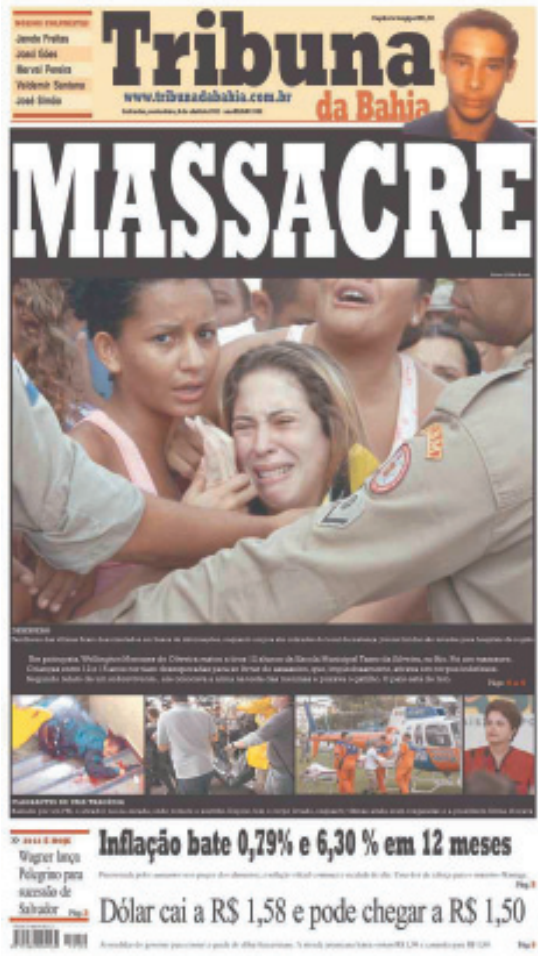

Figura 9
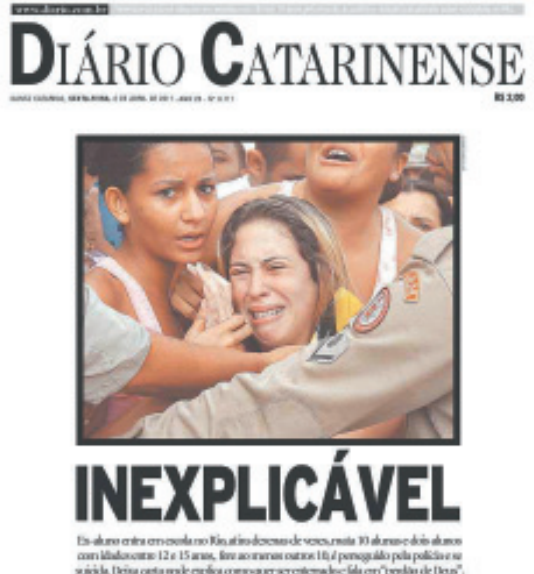

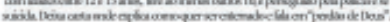

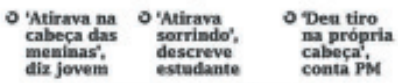

Fonte: Diário Catarinense

Fonte: Tribuna da Bahia

Em sete das 14 capas nas quais a fotografia foi publicada, as legendas contêm o substantivo "desespero" ou o verbo "desesperar". A contundência das legendas e das manchetes indica a capacidade denotativa do registro. O repórter fotográfico, ao usar uma lente teleobjetiva, que reduz o campo de abrangência fechando a tomada da imagem, provocou a seletividade de foco, concentrando a atenção no ponto focado, ou seja, a mulher e seu choro, o que leva a um entendimento geral - porém jamais único - de que sua intencionalidade de comunicação era a de traduzir para seus leitores o desespero da fotografada.

Em cinco capas, a legenda trata os personagens como parentes ou familiares, talvez até por se apoiarem na informação da legenda original do repórter fotográfico Jadson Marques, que não checou se eram mesmo 
parentes, apenas transeuntes ou talvez moradores do bairro. Em dois jornais, Jornal da Cidade e Jornal de Jundiaí (Figura 7), a mulher que chora é descrita nas legendas como mãe de aluno ou vítima, informação que provavelmente não foi checada pelos jornais, ambos do interior do estado de São Paulo e, ao que consta, não têm correspondentes na cidade do Rio de Janeiro. "Mãe" é um laço que certamente reforça a mensagem de desespero.

Lima (1988) defende que a fotografia é produto da relação espaço/ tempo e que a legenda é fruto desta relação, contendo informações sobre o acontecimento, quando e onde. Em somente cinco das 14 capas, o local de ocorrência foi identificado, informação contida na legenda original do repórter fotográfico, ou seja, em frente à escola. Esta fotografia, aliás, é fortemente conotada por seu autor que, ao fechar o ângulo, reforçou ainda mais a ideia de desespero. Ao fazer este recorte, a fotografia perde os referentes do local, impedindo a identificação visual do espaço do acontecimento. Assim, para quem vê, a cena poderia se passar em frente à escola ou na frente do hospital para onde foram levadas as vítimas. A função da legenda, para casos como esse, como enfatiza Joly (2003), seria de complementaridade. As legendas de $O$ Estado de $S$. Paulo e $A$ Notícia são as que mais se aproximam da legenda original do fotógrafo.

Segundo Santos (2005, p.1091), o papel da legenda é “dizer o que não se vê, a partir do que se vê". É recomendável muita cautela com esta definição. Alegenda do jornal Tribuna da Bahia (Figura 8), por exemplo, afirma que os "familiares estão em busca de informações, que corpos são retirados do local e jovens levados para hospital da região". Nenhuma dessas informações está na fotografia. Esta segunda mensagem é rapidamente, como diz Barthes (1990), “devorada" pela imagem, e não há conexão entre esta e o texto por meio da legenda.

No Jornal de Jundiaí (Figura 7), a primeira parte da legenda dá um significado novo à mulher, ao descrevê-la como mãe, e a segunda parte claramente emite uma "opinião": "Mãe de aluno chora diante da escola onde aconteceu, ontem, a tragédia mais cruel de toda a história do Brasil. Ataque já marcou os EUA mais de uma vez, agora, choca o Brasil’" 
Seria função da legenda fotográfica emitir "opinião", como aponta o manual de redação de $O$ Estado de S. Paulo? (MARTINS, 1997, p.159). Contraditoriamente, o mesmo manual orienta, na página 204, que as opiniões devem ser expressas nos espaços adequados, nos editoriais, e que o noticiário deve ser essencialmente informativo.

Chama a atenção também a legenda do jornal Comércio de Franca: "Amparada por policiais, familiar de aluno se desespera em frente ao colégio". Barthes (1990) diz que na mensagem fotográfica não há códigos, portanto ela é contínua. Por ser polissêmica, ela pode ser entendida de diversas formas por públicos diversos. Na legenda, a mulher que está atrás dos braços de policiais (que parecem ser bombeiros pelas características e cor das fardas) aparece "amparada por policiais". Leitores que tiveram acesso a outras fotografias desta cena, mais abertas e que localizam a escola, e telespectadores que viram essa imagem na televisão, interpretaram que a imagem mostrava uma mulher não amparada, e sim barrada por policiais. "Barrada por policiais", pela lógica dos editores, no entanto, não combinaria e nem reforçaria o discurso da manchete: “Deus, por quê?". Ao que tudo indica, os editores interpretaram que "amparada" conotaria melhor a imagem e enfatizaria mais a mensagem da manchete.

O Diário de Natal usou a estratégia de uma única legenda para quatro imagens totalmente diferentes. Esta legenda só diz respeito a uma das quatro imagens, a da reprodução da carta deixada pelo assassino. Portanto, ela não cumpre função alguma em relação à fotografia analisada, que está estampada no jornal unicamente como ilustração.

A Tarde e $O$ Popular legendaram o registro fotográfico de maneira muito parecida e genérica, "parentes ou familiares desesperados atrás de notícias dos alunos", banalizando a mensagem da fotografia. Guran (2002) chama a atenção para este tipo de legenda que, segundo ele, não funciona como "gatilho mental", ou seja, não desperta no leitor curiosidade alguma, nem o reporta à exploração de significados menos evidentes.

Por ser uma imagem com mensagem fortemente denotada, esta fotografia foi usada em cinco periódicos, sem legenda alguma: $O$ Dia, 
Jornal de Brasília, O Norte, Diário do Pará e Diário Catarinense (Figura 9). Neste último, inclusive, é a única imagem utilizada e ocupa quase toda a capa, acompanhada da manchete: "INEXPLICÁVEL".

\section{Considerações finais}

As diversas legendas fotográficas elaboradas por jornais brasileiros, de várias regiões, para as fotografias analisadas neste trabalho mostram a necessidade de uma maior discussão e debate acerca das funções que elas teriam para a mediação entre o texto e a imagem. Foram identificados quatro aspectos de sua função informativa neste estudo:

1) "Conteúdo": abastecer o leitor com as informações que não estão na fotografia, e que ele necessita para poder situar a imagem em relação à notícia, local onde se passa a cena, quando se passa, e quem está nela, ou seja, informações que não se encontram na mensagem iconográfica.

2) "Descrição": descrição literal da fotografia.

3) “Opinião": a opinião, na legenda, geralmente estará desconectada com a imagem visualizada pelo leitor.

4) "Ficcional": algo inventado, que não diz respeito à imagem iconográfica

O que se pôde perceber na seleção das 19 capas de jornais são questões de duas ordens: primeiro, as informações obtidas pelo repórter fotográfico não eram precisas, e, sem qualquer forma de checagem, a mulher que chora foi supostamente identificada como "mãe" ou "parente" das vítimas. Esta lacuna de informações imprecisas induz às legendas genéricas, por vezes, inclusive, contrárias à imagem iconográfica. Isso ocorre com muita frequência no dia a dia do jornalismo. Segundo, o que se constatou em algumas legendas foi a tentativa de adequar a mensagem fotográfica ao texto e ao discurso do veículo de comunicação. Mensagens distintas que não refletem única e exclusivamente uma mulher chorando ou o assassino caído na escada foram atribuídas às fotografias nas legendas: "após ser atingido por um PM no abdômen e cometer suicídio com um 
tiro na boca", "deixou carta com teor religioso e orientação sobre o funeral", "“[...] enquanto corpos são retirados do local da matança. Jovens feridos são levados para hospital da região", "[...] a tragédia mais cruel de toda história do Brasil. Ataque que já marcou os EUA mais de uma vez, agora, choca o Brasil", "deixou carta de suicídio com referência ao islamismo e diz ser portador do HIV" etc.

Essas legendas e as próprias fotografias quando publicadas sem legendas dão vida à mensagem, expressa pelas respectivas manchetes dos jornais citados: "Matança na escola", "Deus, por quê?", “Ajoelha que vou te matar", "Inexplicável”, "Dor Nacional”, "Manhã de horror”, "Columbine à brasileira", "12 mortos, 190 milhões de feridos", "Ataque brutal", "Ele atirava na cabeça" etc. Tudo leva a crer que as manchetes de cunho sensacionalista - que visam o mercado, precisam de fotografias e, consequentemente, de legendas - reforcem e comprovem o discurso proposto e o projeto editorial de cada jornal. Assim, deduz-se que a maioria das legendas desse corpus não exerceu sua função informativa.

Segundo Guy Debord, o espetáculo apresenta-se como positivo, indiscutível e inacessível e não diz nada além de "o que aparece é bom, o que é bom aparece" (DEBORD,1997, p.17). Ao tratar o caso do Realengo com tanto sensacionalismo, como vimos na edição das manchetes, das fotografias e das legendas, a mídia não estaria contribuindo para que outros jovens com perfis psicológicos alterados seguissem pela mesma trajetória? A civilização da ditadura da imagem, na qual só quem é "visto" participa do espetáculo e pode alcançar a plenitude, atrai esse tipo de jovem que, não raro, se considera excluído.

Esses rapazes que matam seus pares aos montes e, assim, tentam trocar a insignificância pelo superestrelato, que dá picos de audiência e bate recordes de vendagem nas bancas, não estariam saciados e não se sentiriam vingados se cometessem suas atrocidades no escuro, longe das plateias. (BUCCI, 2011).

O Diário de Pernambuco não estaria "perdendo a mão" ao reproduzir a carta do assassino na íntegra em sua primeira página com a 
manchete "12 mortos (em vermelho), 190 milhões de feridos" e, ao lado, reproduzir várias cenas, entre elas, a do assassino morto na escada? Bucci (2011) alerta em seu artigo Deixar a vida para entrar no espetáculo:

O jornalismo não dispõe de argumentos para se recusar a dizer o nome desses criminosos todos. Não tem como não dar a foto. Não pode sonegar às pessoas o que as pessoas querem saber. E têm o direito de saber. Agora: que é perturbador, é muito perturbador. Um sujeito vai lá, mata uma porção de crianças, e ainda ganha de presente a fama adorada, e vazia, pela qual matou - e morreu. E sabemos todos que virão outros.

E veio. Cinco meses depois, em 22 de setembro de 2011, o pequeno Davi, de 10 anos, roubou a arma de seu pai, atirou na professora e depois se suicidou numa escola municipal do ABC Paulista.

\section{Referências}

BARTHES, Roland. O óbvio e o obtuso: ensaios críticos III.

Rio de Janeiro: Nova Fronteira, 1990.

BUCCI, Eugênio. Deixar a vida para entrar no espetáculo.

Observatório da Imprensa, Asão Paulo, n. 636, 2011. Disponível em: $<$ http://migre.me/5U7hi $>$. Acesso em: 11 out. 2011.

CARTIER-BRESSON, Henri. O momento decisivo. Bloch

Comunicação, Rio de Janeiro, n.6, p.19-25, 1965,. Disponível em:

$<$ http://migre.me/5KnA8>. Acesso em: 20 set. 2011.

DEBORD, Guy. A sociedade do espetáculo. Rio de Janeiro:

Contraponto,1997.

GARCIA, Luiz. Manual de redação e estilo de O Globo. 26.ed.

Rio de Janeiro: Globo, 1999. 
GURAN, Milton. Linguagem fotográfica e informação. 3.ed.

Rio de Janeiro: Gama Filho, 2002.

JOLY, Martine. Introdução à análise da imagem. 7.ed. Campinas:

Papirus, 2004.

KOSSOY, Boris. Realidades e ficções na trama fotográfica.

3.ed. Cotia: Ateliê Editorial, 2002.

LIMA, Ivan. A fotografia é a sua linguagem. Rio de Janeiro:

Espaço e Tempo, 1988.

MARTINS, Eduardo. Manual de redação e estilo de O Estado

S. Paulo. 3.ed. São Paulo: O Estado de S. Paulo, 1997.

SANTOS, Jorge Viana. Operadores de tempo em enunciados de legendas jornalísticas. Estudos Linguísticos, São Paulo, v.34, p.1087-1092, 2005. Disponível em: <http://migre.me/5KnCA>. Acesso em: 20 set. 2011.

SILVA, Carlos Eduardo Lins da. Manual da redação da Folha de S. Paulo. 14.ed. São Paulo: Publifolha, 2010. 